\title{
Manajemen Anestesia pada Evakuasi Epidural Haemorrhage (EDH) dengan Pendarahan Masif
}

\author{
Nurul Huda, Buyung Hartiyo Laksono \\ Departemen Anestesiologi dan Terapi Intensif, Fakultas Kedokteran, Universitas Brawijaya-RSUD Dr. Saiful \\ Anwar, Malang, Indonesia
}

\begin{abstract}
Abstrak
Cedera otak traumatik menjadi penyebab dari mortalitas dan morbiditas di seluruh dunia. Epidural Haemorrhage (EDH) merupakan salah satu bentuk cedera otak traumatik dimana waktu adalah indikator yang harus diperhatikan dalam tatalaksananya. Fokus utama selama penatalaksanaan kasus cedera otak traumatik adalah stabilisasi pasien dan mengendalikan tekanan intrakranial, serta mempertahankan oksigenasi dan perfusi otak. Selanjutnya dilakukan dekompresi dengan pembedahan. Evakuasi dan kontrol perdarahan harus dikerjakan dalam waktu singkat untuk menghindari cedera lebih lanjut. Praktik neuroanastesi, sebagai penunjang dalam tatalaksana cedera otak traumatik, sering diasosiasikan dengan kejadian kehilangan darah yang mengakibatkan kondisi anemia selama periode intra operatif dan pasca operatif. Meskipun anemia berkorelasi dengan hasil akhir yang buruk pada pasien cedera otak, transfusi sel darah merah untuk mengoreksi kondisi anemia juga berkorelasi dengan hasil akhir yang buruk pada pasien. Masih belum ada rekomendasi yang jelas mengenai pemberian transfusi, apakah restriksi atau masif, terkait dengan manfaat yang diberikan. Pasien laki-laki, usia 51 tahun dengan keluhan penurunan kesadaran dan muntah-muntah, rujukan dari rumah sakit sebelumnya dengan diagnosis cedera kepala sedang 225 dengan EDH temporoparietal $96 \mathrm{cc}$, midline shift $11 \mathrm{~mm}$ ke kanan, edema serebri. Selama durante operasi terjadi perdarahan masif yang mengganggu status hemodinamik sehingga diberikan transfusi komponen darah sampai didapatkan status hemodinamik yang stabil. Pada perawatan pasca operasi di ICU, kondisi pasien relatif baik.
\end{abstract}

Kata kunci: cedera kepala traumatik, Epidural Haemorrhage (EDH), transfusi

JNI 2021; 10 (1): 29-39

\section{Blood Transfusion Management for Epidural Haemorrhage (EDH) Evacuation with Massive Bleeding}

\begin{abstract}
Traumatic brain injury causes mortality and morbidity worldwide. Epidural Haemorrhage (EDH) is a form of head injury where time is an indicator that must be considered in its management. The main focus during traumatic brain injury management is patient stabilization and control of intracranial pressure, as well as maintaining brain oxygenation and perfusion. Subsequently, surgical decompression was performed. Evacuation and bleeding control should be done in a short time to avoid further injury. The practice of neuroanesthesia, as a support in the management of traumatic brain injuries, is often associated with blood loss that results in anemia during the intraoperative and postoperative periods. Although anemia correlates with poor outcome in brain-injured patients, red blood cell transfusion to correct anemia also correlates with poor outcome in patients. There are still no clear recommendations regarding the administration of transfusions, whether restrictive or massive, regarding the benefits provided. Male patient, age 51 years with complaints of decreased consciousness and vomiting, referred from the previous hospital with a diagnosis of moderate head injury 225 with $96 \mathrm{cc}$ temporoparietal EDH, $11 \mathrm{~mm}$ midline shift to the right, and cerebral edema. During the operation period, there was massive bleeding that interfered with the hemodynamic status so that blood components were transfused until a stable hemodynamic status was obtained. In postoperative care in the ICU, the patient is relatively in good condition.
\end{abstract}

Key words: traumatic brain injury, epidural haemorrhage (EDH), transfusion

JNI 2021; 10 (1): 29-39 


\section{Pendahuluan}

Cedera otak traumatik (COT) adalah adanya gangguan dari fungsi otak yang bersifat nondegeneratif ataupun kongenital yang dapat terjadi karena kekuatan mekanik dari luar, yang menyebabkan penurunan fungsi kognitif, fisik, dan psikososial baik permanen maupun sementara, dan disertai dengan penurunan atau perubahan kesadaran. ${ }^{1}$ Kondisi ini menjadi penyebab utama kematian dan disabilitas akibat cedera kepala di seluruh dunia. Data dari tahun 2013 melaporkan bahwa populasi di atas umur 75 tahun memiliki insiden yang tinggi dengan mayoritas penyebabnya adalah jatuh dari kondisi berdiri atau jatuh dari ketinggian. ${ }^{2}$ Sedangkan dari sumber yang lain menyebutkan bahwa COT menjadi penyebab mortalitas dan morbiditas pada pasien berusia 18-45 tahun, dengan mekanisme kejadian adalah kecelakaan kendaraan bermotor $(62,5 \%)$ dan terjatuh dari ketinggian $(15,6 \%){ }^{3}$ Tatalaksana pasien degan COT menjadi fokus utama untuk mencegah terjadinya cedera otak sekunder akibat berbagai faktor antara lain hipoksemia, hipotensi, hipo/hiperkarbi, hipo/ hiperglikemia, hipo/hipertermi, dan kejang. ${ }^{4}$ Epidural Haemorrhage (EDH) merupakan salah satu bentuk cedera kepala. ${ }^{5}$

Satu penelitian menyebutkan bahwa praktik neuroanastesi, sebagai penunjang dalam tatalaksana COT, sering dihubungkan dengan kejadian kehilangan darah yang mengakibatkan kondisi anemia selama periode intra operatif dan pasca operatif. ${ }^{6}$ Kondisi anemia ini dapat memperparah kerusakan otak karena kebutuhan oksigen ke otak tidak dapat dipenuhi secara optimal. Di sisi lain, didapatkan fakta bahwa transfusi untuk mengatasi kondisi anemia tersebut dapat memicu terjadinya gangguan neurologis pada otak yang sudah mengalami trauma walaupun mekanismenya masih belum dapat dijelaskan. ${ }^{7}$ Pemberian transfusi sel darah merah dapat memperbaiki oksigenasi otak. Namun hematokrit yang rendah ataupun tinggi tidak menunjukkan perbedaan yang signifikan pada hasil akhir pasien. ${ }^{6}$

Pemberian transfusi pada kasus Subarachnoid
Haemorrhage (SAH) diketahui dapat meningkatkan insiden vasospasme dan memberikan hasil akhir yang buruk pada pasien. ${ }^{8}$ Dalam sebuah penelitian multisenter yang melibatkan pasien dengan cedera kepala sedang hingga berat, didapatkan bahwa tidak ada perbedaan yang signifikan pada mortalitas pasien yang diberi transfusi secara masif dan restriktif. Sedangkan strategi transfusi yang restriktif memberikan insiden yang lebih rendah terhadap kejadian pneumonia, infeksi saluran kemih, bakteremia, dan syok sepsis pada kasus cedera kepala berat. ${ }^{9}$ Bukti ilmiah terbaru menyarankan target hemoglobin $(\mathrm{Hb})$ dalam rentang 8-9 g/ dL selama intra operatif. Tetapi batasan minimal untuk kadar $\mathrm{Hb}$ yang harus dicapai selama prosedur bedah saraf masih belum ditetapkan. ${ }^{6}$

Hingga saat ini dapat disimpulkan meskipun anemia berkorelasi dengan hasil akhir yang buruk pada pasien cedera otak, pemberian transfusi sel darah merah untuk mengoreksi kondisi anemia juga tidak memberikan hasil akhir yang baik. Masih belum ada rekomendasi yang jelas mengenai pemberian transfusi, apakah restriksi atau masif, terkait dengan manfaat yang diberikan pada pasien dengan COT. Sehingga pada praktik klinis, saat ini lebih ditekankan pada pendekatan individual mengenai target $\mathrm{Hb}$ optimal berdasarkan indikator fisiologis dari cidera otak yang terjadi pada masing-masing pasien. ${ }^{10}$ Berbekal dari latar belakang tersebut, penulis mencoba menerapkan tatalaksana transfusi yang ideal pada kasus yang dipaparkan. Diharapkan hasil akhir pada pasien yang diberi tatalaksana yang ideal dapat relatif baik.

\section{Kasus}

\section{Anamnesis}

Pasien laki-laki 51 tahun, datang dengan penurunan kesadaran sejak 19 jam yang lalu. Sehari sebelum pasien datang, pasien terjatuh dari tangga dengan ketinggian tiga meter dan sempat pingsan. Setelah sadar, pasien dibawa ke puskesmas serta dilakukan penjahitan di telinga kiri. Pasien selanjutnya dibawa ke pengobatan alternatif (sangkal putung) untuk pijat tangan kanan. Pasien kemudian mengalami muntah dan 
kehilangan kesadaran. Pasien kemudian dibawa ke rumah sakit.

\section{Pemeriksaan Fisik}

Breath (B1) didapatkan airway paten, napas spontan, RR 20x/menit, $\mathrm{SpO}_{2} 100 \%$, gerak dinding simetris kiri dan kanan, vesikular $+/+$, rhonki -/-, wheezing -/-. Bleed (B2) akral hangat kering merah, CRT $<2$ detik, nadi $57 \mathrm{x} /$ menit, reguler tekanan darah 133/96 $\mathrm{mmHg}$, S1S2 tunggal, reguler, murmur (-), gallop (-). Brain (B3) Glasglow Coma Scale (GCS) 225, RC (+),

Tabel 1. Pemeriksaan Penunjang

\begin{tabular}{|c|c|c|c|}
\hline Penemuan Laboratorium & & Nilai & \\
\hline $\mathrm{Hb}$ & 11,40 & $\mathrm{~g} / \mathrm{dL}$ & $13,4-17,7$ \\
\hline WBC & 18.000 & $/ \mu \mathrm{L}$ & $4.700-11,300$ \\
\hline Hematocrite & 33,20 & $\%$ & $40-47$ \\
\hline PLT & 216.000 & $/ \mu \mathrm{L}$ & $142.000-424.000$ \\
\hline $\mathrm{MCV}$ & 86,50 & $\mathrm{fL}$ & $80-93$ \\
\hline $\mathrm{MCH}$ & 29,70 & $\mathrm{Pg}$ & $27-31$ \\
\hline $\mathrm{MCHC}$ & 34,30 & $\mathrm{~g} \%$ & $32-36$ \\
\hline Eosinophil & 0,0 & $\%$ & $0-4$ \\
\hline Basophil & 0,1 & $\%$ & $0-1$ \\
\hline Neutrophil & 15,31 & $\%$ & $51-67$ \\
\hline Lymphocyte & 1,46 & $\%$ & $25-33$ \\
\hline Monocyte & 1,21 & $\%$ & $2-5$ \\
\hline Ureum & 36,6 & $\mathrm{mg} / \mathrm{dL}$ & $16,6-48,5$ \\
\hline Creatinine & 1,32 & $\mathrm{mg} / \mathrm{dL}$ & $<1,2$ \\
\hline SGOT & 25 & $\mathrm{U} / \mathrm{L}$ & $0-32$ \\
\hline SGPT & 13 & $\mathrm{U} / \mathrm{L}$ & $0-33$ \\
\hline PPT pasien/kontrol/INR & $9,90 / 10,8 / 0,95$ & detik & \\
\hline APTT pasien/kontrol & $26,50 / 26,3$ & detik & \\
\hline Natrium & 138 & $\mathrm{mmol} / \mathrm{L}$ & $136-145$ \\
\hline Potassium & 3,86 & $\mathrm{mmol} / \mathrm{L}$ & $3,5-5,0$ \\
\hline Chloride & 119 & $\mathrm{mmol} / \mathrm{L}$ & $98-106$ \\
\hline CRP kuantitatif & 4,63 & $\mathrm{mg} / \mathrm{dL}$ & \\
\hline Procalcitonin & 0,26 & $\mathrm{ng} / \mathrm{mL}$ & \\
\hline BGA & & Value & \\
\hline $\mathrm{pH}$ & 7,41 & & $7.35-7.45$ \\
\hline $\mathrm{pCO}_{2}$ & 29,1 & $\mathrm{mmHg}$ & $35-45$ \\
\hline $\mathrm{pO}_{2}$ & 131,7 & $\mathrm{mmHg}$ & $80-100$ \\
\hline $\mathrm{HCO}_{3}$ & 18,6 & $\mathrm{mmol} / \mathrm{L}$ & $21-28$ \\
\hline $\mathrm{BE}$ & $-6,3$ & $\mathrm{mmol} / \mathrm{L}$ & $-3-+3$ \\
\hline Saturasi $\mathrm{O}_{2}$ & 98,8 & $\%$ & $>95$ \\
\hline $\mathrm{Hb}$ & 11,4 & $\mathrm{~g} / \mathrm{dL}$ & \\
\hline Suhu & 37 & ${ }^{\circ} \mathrm{C}$ & \\
\hline
\end{tabular}


pupil isokor $3 \mathrm{~mm} / 3 \mathrm{~mm}$, lateralisasi (-). Bladder (B4) BAK (+) on kateter, produksi urin $200 \mathrm{cc} / 2$ jam. Bowel (B5) bising usus (+) kesan normal, distensi abdomen (-), nyeri tekan (-). Bone (B6) tidak didapatkan edema pada kedua tungkai, dan sianosis.

\section{Pemeriksaan Penunjang}

Pasien dinilai dengan ASA 4E. Dari CT Scan, didapatkan cedera kepala sedang 225 dengan EDH temporoparietal $96 \mathrm{cc}$, midline shift $11 \mathrm{~mm}$ ke kanan disertai edema serebri (Gambar 1). Rontgen toraks tidak ditemukan kelainan (Gambar 2). Hasil laboratorium terdapat dalam tabel 1. Tatalaksana yang akan dikerjakan pada pasien adalah trepanasi, dekompresi, evakuasi EDH dengan anestesi umum intubasi. Dilakukan juga pemasangan CVC, dan rencana post op perawatan di ICU.

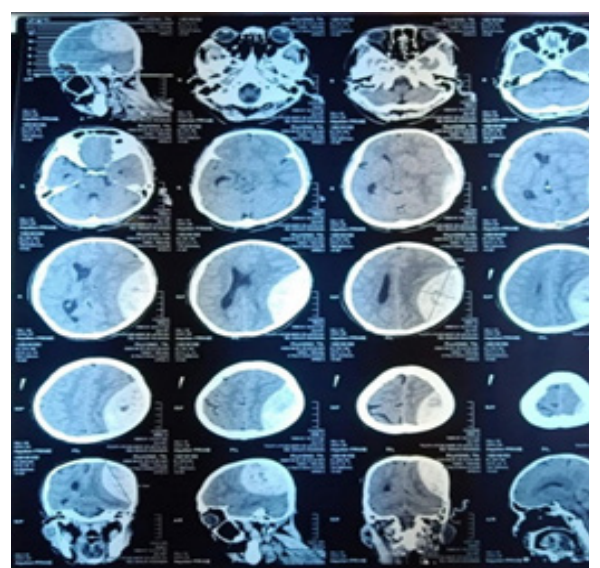

Gambar 1. Thorax x Ray (25/09/2020) tidak ditemukan kelainan

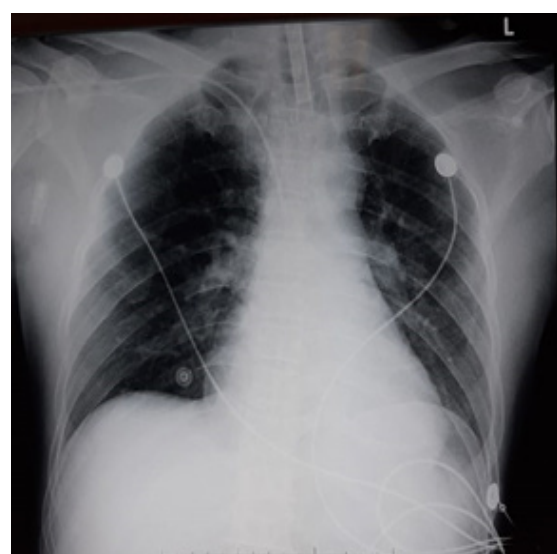

Gambar 2. CT Scan kepala didapatkan EDH Temporoparietal S 96 cc, mid line shift kanan 11 mm.
Durante Operasi

Di kamar operasi, pasien diposisikan dalam posisi supinasi dengan kepala head up $15-30^{\circ}$ netral. Pasien dipasang alat-alat monitor noninvasif (tekanan darah, denyut jantung, $\mathrm{EKG}, \mathrm{SaO}_{2}$ ) dan kateter urin. Pasien dilakukan induksi dengan pemberian midazolam 2,5 mg, fentanyl $200 \mathrm{mcg}$, lidocain $80 \mathrm{mg}$, propofol titrasi 100 $\mathrm{mg}$, vecuronium $6 \mathrm{mg}$. Rumatan anestesi dengan sevoflurane dengan $\mathrm{O}_{2}$ : udara (50:50), propofol kontinyu fentanyl kontinyu $0,5-1 \mu \mathrm{g} / \mathrm{KgBB} /$ jam dan vecuronium kontinyu $1-2 \mu \mathrm{g} / \mathrm{KgBB} /$ menit. Setelah intubasi dilakukan pemasangan catheter vena central (CVC) subklavia kanan.
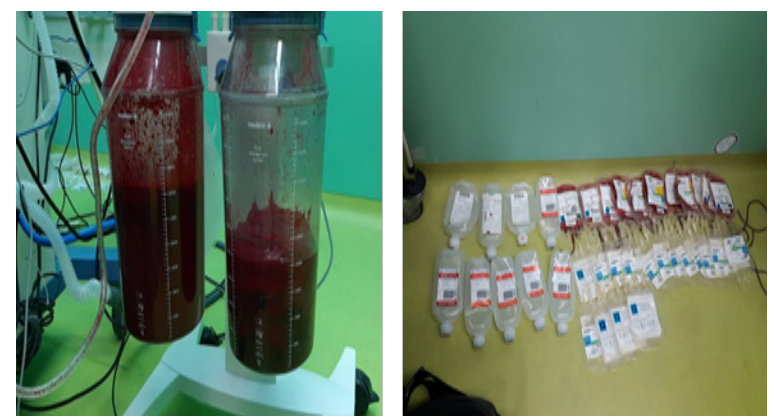

Gambar 3. Pendarahan Selama Durante Operasi

Operasi berlangsung selama 3 jam. Pemberian cairan intra operatif, pasien diberikan input cairan sebagai berikut; kristaloid $3000 \mathrm{cc}$, koloid $1900 \mathrm{cc}$, komponen Whole Blood (WB) $1050 \mathrm{cc}$, Packed Red Cell (PRC) 1933 cc, Thrombocyte Concentrates (TC) 720 cc, Fresh Frozen Plasma

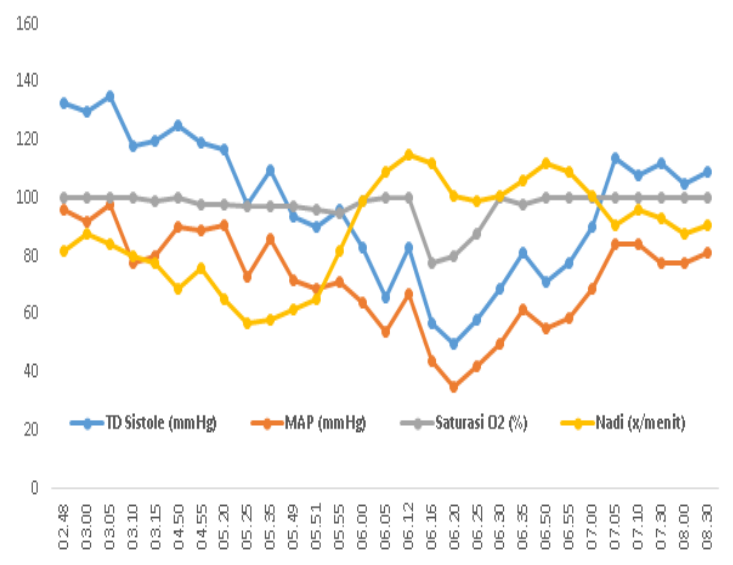

Grafik 1. Status Hemodinamik Pasien Selama Durante Operasi 
Tabel 2. Pemeriksaan Penunjang Pasca Operasi

\begin{tabular}{llll}
\hline Penemuan Laboratorium & \multicolumn{3}{l}{ Nilai } \\
\hline $\mathrm{Hb}$ & 14,3 & $\mathrm{~g} / \mathrm{dL}$ & $13,4-17,7$ \\
$\mathrm{WBC}$ & 12.820 & $/ \mu \mathrm{L}$ & $4.700-11,300$ \\
$\mathrm{Hematocrite}$ & 40,3 & $\%$ & $40-47$ \\
$\mathrm{PLT}$ & 131.000 & $/ \mu \mathrm{L}$ & -424.000 \\
$\mathrm{Ureum}$ & 28,4 & $\mathrm{mg} / \mathrm{dL}$ & $16,6-48,5$ \\
Creatinine & 0,55 & $\mathrm{mg} / \mathrm{dL}$ & $<1,2$ \\
Albumin & 3,84 & & \\
GDS & 206 & & \\
Natrium & 140 & $\mathrm{mmol} / \mathrm{L}$ & $136-145$ \\
Potassium & 3,16 & $\mathrm{mmol} / \mathrm{L}$ & $3,5-5,0$ \\
Chloride & 115 & $\mathrm{mmol} / \mathrm{L}$ & $98-106$ \\
$\mathrm{PF}$ ratio & 255 & & \\
\hline Blood Gas Analysis $(\mathrm{BGA})$ & $\mathrm{Nilai}$ & $7.35-7.45$ \\
\hline $\mathrm{pH}$ & 7,36 & & $35-45$ \\
$\mathrm{pCO}_{2}$ & 41,5 & $\mathrm{mmHg}$ & $80-100$ \\
$\mathrm{pO}_{2}$ & 101,7 & $\mathrm{mmHg}$ & $21-28$ \\
$\mathrm{HCO}_{3}$ & 23,9 & $\mathrm{mmol} / \mathrm{L}$ & $-3-+3$ \\
$\mathrm{BE}$ & $-1,7$ & $\mathrm{mmol} / \mathrm{L}$ & $>95$ \\
$\mathrm{Saturasi}_{2}$ & 97,5 & $\%$ & \\
\hline
\end{tabular}

(FFP) 725 cc. Sedangkan output cairan diuresis $1000 \mathrm{cc}$, darah $7000 \mathrm{cc}$, dan M+O 900 cc sehingga didapatkan balans cairan sebanyak $-916 \mathrm{cc}$. Pada kasus pasien ini, saat terjadi perdarahan masif selama durante operasi untuk evakuasi EDH, juga dilakukan metode transfusi restriktif serta tetap memperhatikan kondisi klinis pasien saat itu daripada memfokuskan pada target $\mathrm{Hb}$ yang harus dicapai. Gambar 3 menunjukkan status hemodinamik pasien selama durante operasi. Dapat dilihat selama rentang waktu pukul 06.1206.35 terjadi penurunan grafik yang berarti terjadi ketidakstabilan hemodinamik pasien. Kondisi klinis ini akibat perdarahan sehingga dilakukan transfusi komponen darah sebanyak 4628 cc dengan deskripsi sebagai berikut: WB 1050 cc, PRC 1933 cc, TC 720 cc, FFP 725 cc menggunakan metode restriksi. Setelah beberapa waktu, kondisi klinis membaik yang ditunjukkan dengan peningkatan pada grafik.

\section{Pascaoperasi}

Pascabedah, pasien dirawat di Unit Perawatan

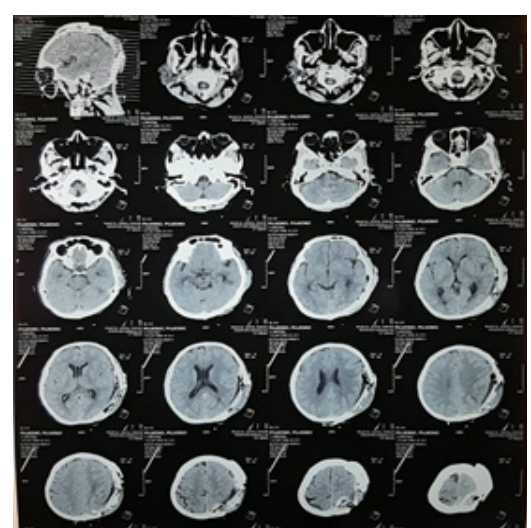

Gambar 4. CT Scan Control Post dilakukan TDE EDH

Intensif (Intensive Care Unit/ ICU) selama 2 hari sebelum dipindahkan ke ruangan. Pasien dirawat dalam kontrol ventilator, analgetik fentanyl 30 $\mu \mathrm{g} / \mathrm{jam}$, midazolam $2 \mathrm{mg} / \mathrm{jam}$. Hari pertama di ICU, hemodinamik pasien stabil dengan tekanan arteri rata-rata $80-95 \mathrm{mmHg}$, laju nadi $67-90 \mathrm{kali} /$ menit, saturasi $\mathrm{O}_{2} 99 \%$. Pasca dilakukan CT scan control (Gambar 4), dan tidak didapatkan adanya 
tanda pendarahan berulang, pasien dilakukan proses weaning dan dilakukan ekstubasi. Hari kedua perawatan ICU terjadi trend peningkatan GCS 435-436. Pada hari ke tiga pasien pindah ke High Care Unit (HCU) bedah dengan kondisi hemodinamik stabil dengan GCS 456. Hasil pemeriksaan pasca operasi terdapat dalam tabel 2 .

\section{Pembahasan}

Cedera otak traumatik (COT) adalah adanya gangguan dari fungsi otak yang bersifat nondegeneratif ataupun kongenital yang dapat terjadi karena kekuatan mekanik dari luar, yang menyebabkan penurunan fungsi kognitif, fisik, dan psikososial baik permanen maupun sementara, dan disertai dengan penurunan atau perubahan kesadaran. Kondisi ini menjadi penyebab utama kematian dan disabilitas di seluruh dunia. Data dari tahun 2013 melaporkan bahwa populasi di atas umur 75 tahun memiliki insiden yang tinggi dengan mayoritas penyebabnya adalah jatuh dari kondisi berdiri atau jatuh dari ketinggian. Sedangkan dari sumber yang lain menyebutkan bahwa COT menjadi penyebab mortalitas dan morbiditas pada pasien berusia 18-45 tahun, dengan mekanisme kejadian adalah kecelakaan kendaraan bermotor $(62,5 \%)$ dan terjatuh dari ketinggian (15,6\%). Epidural haemorrhage (EDH) merupakan salah satu bentuk cedera kepala. $^{1,2}$

Pada kasus ini, pasien mengalami mekanisme kejadian terjatuh dari ketinggian kurang lebih 3 meter. Awalnya pasien masih sadar dan dibawa ke puskesmas untuk dilakukan penjahitan pada telinga kiri. Pasien juga sempat pergi ke sangkal putung untuk pijat tangan kanan. Karena pasien muntah-muntah dan tidak sadar, lalu pasien dibawa ke rumah sakit. Kondisi ini merupakan kondisi khas dari kasus Epidural haemorrhage (EDH) yang dikenal dengan istilah lucid interval yaitu penurunan kesadaran singkat lalu diikuti periode sadar kembali yang dapat berlangsung beberapa jam sebelum fungsi otak memburuk bahkan hingga menyebabkan kondisi koma. Gejala lain yang dapat menyertai EDH yaitu nyeri kepala, muntah, dan kejang. Apabila kondisi ini tidak ditangani dengan cepat, EDH yang terjadi akan semakin luas dan progresif sehingga menyebabkan herniasi transtentorial progresif dengan tanda klinis seperti extensor posturing, pupil dilatasi, pupil anisokor, perburukan neurologis progresif (GCS turun $>2$ dari GCS terbaik sebelumnya, dengan permulaan GCS $<9)$ hingga kematian. ${ }^{9}$ Epidural haemorrhage terjadi akibat benturan hebat sehingga merobek pembuluh darah meninges dan menyebabkan perdarahan. Sumber perdarahan biasanya berasal dari arteri sehingga status neurologis pasien dapat turun dengan cepat. Tatalaksana EDH difokuskan pada waktu sehingga evakuasi dan kontrol perdarahan dengan segera sangat penting untuk keselamatan pasien dan mencegah defisit neurologis permanen. ${ }^{10}$

Pada kasus ini, pasien mengalami keterlambatan hingga lebih dari 6 jam dari kejadian, sehingga didapatkan perdarahan yang sangat masif dari hasil pemeriksaan CT scan kepala dan menyebabkan midline shift. Indikasi dilakukan tindakan operatif pada kasus cedera otak traumatik apabila ditemukan massa yang bermakna seperti herniasi serebral atau pergeseran garis tengah (midline shift) lebih atau sama dengan $5 \mathrm{~mm}$ yang diketahui dari pemeriksaan CT scan potongan aksial. Pada kasus EDH dengan volume perdarahan lebih dari $30 \mathrm{cc}$ tanpa keluhan atau EDH dengan GCS $<9$ disertai dilatasi pupil juga harus dilakukan evakuasi perdarahan dan dekompresi segera. Evakuasi pada kasus EDH akut dapat dikerjakan dengan kraniotomi ataupun kraniektomi. ${ }^{11}$ Pada kasus ini, indikasi dilakukan tindakan operatif secara klinis adalah perdarahan yang semakin masif dan progresif yang diketahui dari turunnya GCS pasien. Sedangkan secara pemeriksaan penunjang CT scan kepala, didapatkan volume perdarahan di lobus temporoparietal sinistra sebesar $96 \mathrm{cc}$ dan midline shift kanan $11 \mathrm{~mm}$. Penanganan COT sangat terkait dengan tugas ahli anestesi sesuai dengan prinsip pengelolaan anestesi pada operasi bedah saraf, yakni harus dilakukan manajemen ABCDE (airway, breathing, circulation, drugs dan environment). Airway, jalan napas harus selalu bebas sepanjang waktu. Breathing, ventilasi untuk mendapatkan oksigenasi yang adekuat. Circulation, hindari lonjakan tekanan 
darah untuk mencegah terjadinya edema berat dan kenaikan tekanan intrakranial dan hindari faktorfaktor mekanis yang meningkatkan tekanan vena serebral. Drugs, gunakan obat-obatan anestesi yang memberikan efek neuroprotektif. Environment, pertahankan suhu hipotermia ringan $\left(35^{\circ} \mathrm{C}\right.$, core temperature). Fokus utama selama penatalaksanaan kasus COT adalah stabilisasi pasien dan mengendalikan tekanan intra kranial, serta mempertahankan oksigenasi dan perfusi otak. Selanjutnya dilakukan dekompresi dengan pembedahan. Waktu adalah indikator yang harus diperhatikan pada kasus EDH. Evakuasi dan kontrol perdarahan harus dikerjakan dalam waktu singkat untuk menghindari cedera lebih lanjut. ${ }^{12}$

Penggunaan obat anestesi harus dipilih dengan seksama, harus dihindari obat-obatan yang dapat meningkatkan tekanan intra kranial dan mengganggu hemodinamik seperti ketamin dan narkotik analgesik. Obat yang digunakan harus dapat menurunkan tekanan intra kranial dengan meningkatkan resistensi vaskuler serebral, menurunkan aliran darah otak, menurunkan volume darah otak, dan menurunkan metabolisme otak. Mekanisme seperti ini yang pada akhirnya akan memberikan efek neuroprotektif. ${ }^{13}$ Anestesi intravena seperti propofol dan fentanyl dapat menurunkan aliran darah otak, metabolisme otak, dan menurunkan tekanan intra kranial secara signifikan. Penting juga mengurangi respon stres selama intubasi dan mempercepat pemulihan pasca bedah. Target utama pengelolaan anestesi pada pasien COT adalah optimalisasi tekanan perfusi otak dan oksigenasi otak, menghindari cedera otak sekunder, dan memberikan fasilitas pembedahan yang optimal. Tatalaksana anestesi harus menjamin adekuasi fungsi respirasi dan sirkulasi. Seperti yang telah disebutkan sebelumnya, bahwa praktik neuroanastesi sering diasosiasikan dengan kejadian kehilangan darah masif yang mengakibatkan kondisi anemia selama periode intra operatif dan pasca operatif. Sedangkan juga diketahui bahwa kondisi anemia dapat memperparah kerusakan otak karena kebutuhan oksigen ke otak tidak dapat dipenuhi secara optimal. Di sisi lain, didapatkan fakta bahwa transfusi untuk mengatasi kondisi anemia tersebut dapat memicu terjadinya gangguan neurologis pada otak yang sudah mengalami trauma walaupun mekanismenya masih belum dapat dijelaskan. ${ }^{4}$ Beberapa hal yang harus diperhatikan sebelum pembedahan pada kasus EDH antara lain pasien harus diposisikan supinasi dengan kepala head up $15-30^{\circ}$ netral. Pemberian mannitol juga harus tetap berjalan untuk menjaga tekanan intra kranial dalam batas normal dengan dosis 1 gram $/ \mathrm{kgBB}$. Selama durante operasi kasus $\mathrm{EDH}$, posisi pasien juga dipertahankan supinasi dengan head up $15-30^{\circ}$ netral. Pada pengelolaan pasca bedah, pasien juga tetap harus diposisikan head up $15-20^{\circ} .^{14}$

Permasalahan pada pasien ini adalah saat pertama kali datang dari rumah sakit sebelumnya, sudah terjadi perdarahan otak yang masif ditambah dengan keterlambatan penanganan sejak onset kejadian. Terbukti dari banyaknya volume perdarahan yang terjadi yaitu sebesar $96 \mathrm{cc}$ di lobus temporoparietal sinistra bahkan hingga terjadi midline shift kanan $11 \mathrm{~mm}$. Mengingat risiko kehilangan darah yang bisa terjadi selama durante operasi, pasien sudah dilakukan persiapan seoptimal mungkin. Dilakukan pemeriksaan faal hemostasis preoperasi, didapatkan hasil yang normal, sehingga apabila terjadi perdarahan yang masif, mekanisme hemostasis secara fisiologis dari tubuh pasien dapat mengompensasi dan tidak memperburuk kondisi pasien. Hingga saat ini belum ada protokol yang mengatur pasti bagaimana transfusi sebaiknya dikerjakan saat terjadi perdarahan masif intraoperatif. Batasan minimal kadar $\mathrm{Hb}$ yang dapat diterima selama prosedur pembedahan saraf juga masih belum diketahui pasti. Namun seperti yang telah banyak diketahui bahwa kebutuhan metabolisme otak yang tinggi dapat menyebabkan otak rentan terhadap cedera, terutama pada konsentrasi $\mathrm{Hb}$ rendah atau hematokrit (Hct) rendah. Trauma otak dapat lebih buruk kondisinya bahkan pada kadar $\mathrm{Hb}$ di atas $7 \mathrm{mg} / \mathrm{dL} .{ }^{14}$ Klinisi dari berbagai senter masih menggunakan strategi transfusi yang bervariasi. Dalam beberapa penelitian multisentris yang membandingkan pasien dengan cedera kepala sedang hingga berat, didapatkan hasil bahwa tidak ada perbedaan signifikan pada perbaikan mortalitas pasien yang diberi strategi transfusi liberal ataupun strategi transfusi 
Tabel 3. Perbandingan Manfaat dan Kerugian Transfusi pada Praktik ${ }^{6}$

\begin{tabular}{|c|c|c|c|}
\hline $\begin{array}{l}\text { Cedera Otak } \\
\text { Traumatik }\end{array}$ & $\begin{array}{l}\text { Peningkatan Oksigenasi } \\
\text { jaringan otak } \\
\text { Kelangsungan hidup } \\
\text { lebih dengan rata-rata } 7 \\
\text { hari } \mathrm{Hb}>90 \mathrm{~g} / \mathrm{L}\end{array}$ & $\begin{array}{l}\text { Insiden Pneumonia, bakteremia, } \\
\text { dan syok septik yang lebih } \\
\text { tinggi tidak ada perbaikan } \\
\text { dalam metabolisme otak pada } \\
\text { mikrodialisis secebral }\end{array}$ & $9>\mathrm{g} / \mathrm{dr}$ \\
\hline Aneurisma SAH & $\begin{array}{l}\mathrm{Hb}>90 \mathrm{~g} / \mathrm{L} \text {, menurunkan } \\
\text { insidens hipoksia } \\
\text { serebral disfungsi } \\
\text { energi sel meningkatnya } \\
\text { pengiriman oksigen } \\
\text { serebral tanpa } \\
\text { menurunkan global CBF } \\
\text { (terlihat pada PET) }\end{array}$ & $\begin{array}{l}\text { Viskositas meningkat sehingga } \\
\text { CBF menurun }\end{array}$ & $9>\mathrm{g} / \mathrm{dr}$ \\
\hline $\begin{array}{l}\text { Operasi tumor } \\
\text { intrakranial operasi } \\
\text { spinal bedah saraf } \\
\text { anak }\end{array}$ & $\begin{array}{l}\text { Digunakan untuk } \\
\text { pengganti volume } \\
\text { selama MBL } \\
\text { Meningkatkan kapasitas } \\
\text { pembawa oksigen } \\
\text { setelah 24-48 jam } \\
\text { rFVIIa membantu } \\
\text { mengontrol mikro } \\
\text { vaskuler selama operasi } \\
\text { tumor otak }\end{array}$ & $\begin{array}{l}\text { Faktor risiko independent untuk } \\
\text { perkembangan kanker karena } \\
\text { efek imunomodulator Tranfusi } \\
\text { darah masif menyebabkan DIC } \\
\text { Tranfusi darah autologus dari } \\
\text { cell saver dapat menyebabkan } \\
\text { deposisi tumor seedling }\end{array}$ & $\begin{array}{l}\text { Selama periode MBL, } \\
\text { tranfusi dipandu } \\
\text { oleh perkembangan } \\
\text { hemodinamik arteri } \\
\text { CVP selama periode } \\
\text { keseimabangan } \\
\text { hemodinamik, pemberian } \\
\text { transfusi absolut pada hb } \\
\text { 7-8 g /dl dapat digunakan } \\
\text { sebagai panduan untuk } \\
\text { transfusi }\end{array}$ \\
\hline $\begin{array}{l}\text { Stroke iskemik } \\
\text { akut }\end{array}$ & $\begin{array}{l}\text { Meningkatkan } \\
\text { pengiriman oksigen otak }\end{array}$ & $\begin{array}{l}\text { Peningkatan Hct juga dapat } \\
\text { menjadi denterminan fisiologis } \\
\text { pontensial untuk mengurangi } \\
\text { penyelamatan penumbra Nilai } \\
\text { Hct yang lebih tinggi memiliki } \\
\text { hubungan yang signifikan dengan } \\
\text { berkurangnya reperfusi dan } \\
\text { ukuran infark yang lebih besar } \\
\text { setelah stroke iskemik }\end{array}$ & $\begin{array}{l}\text { Target } \mathrm{Hb} \text { untuk intervensi } \\
\text { pada stroke emboli akut } \\
\text { tidak diketahui Hb } 13 \mathrm{~g} / \mathrm{dl} \\
\text { pada wanita mungkin tidak } \\
\text { sesuai }\end{array}$ \\
\hline
\end{tabular}

Tabel 4. Penelitian yang Mempengaruhi Praktik Transfusi ${ }^{6}$

\begin{tabular}{|c|c|}
\hline Penelitian & Kesimpulan \\
\hline $\begin{array}{l}\text { McIntyre et al } \\
2006\end{array}$ & $\begin{array}{l}\text { Tidak ada perbedaan dalam liberal }(\mathrm{Hb} \text { antara } 10.0 \text { dan } 12.0 \mathrm{~g} / \mathrm{dl}) \text { dan tranfusi restrik- } \\
\text { tif }(\mathrm{Hb} 7.0 \text { dan } 9.0 \mathrm{~g} / \mathrm{dl})\end{array}$ \\
\hline $\begin{array}{l}\text { Leal-Noval et al } \\
2006\end{array}$ & $\begin{array}{l}\text { Transfusi eritrosit menyebabkan oksigen serebral yang lebih baik pada TBI. Tingkat } \\
\mathrm{PtiO}_{2} \text { dasar yang rendah }(<15 \mathrm{mmHg}) \text { paling diuntungkan }\end{array}$ \\
\hline George et al 2008 & $\begin{array}{l}\text { Transfusi restriktif aman untuk pasien cedera kepala dengan insiden pneumonia, bak- } \\
\text { teremia, syok septic yang lebih rendah }\end{array}$ \\
\hline Zygun et 2009 & $\begin{array}{l}\text { Transfusi sel darah merah menghasilkan } \mathrm{PtiO}_{2} \text { yang lebih baik tanpa efek pada marker } \\
\text { metabolisme otak (LPR dan } \mathrm{pH} \text { otak) }\end{array}$ \\
\hline Sekhon et al, 2012 & $\begin{array}{l}\text { Rata-rata konsentrasi } \mathrm{Hb} 7 \text { hari }<90 \mathrm{~g} / \mathrm{L} \text { dikaitkan dengan peningkat mortalitas dis- } \\
\text { umah sakit pada pasien COT berat }\end{array}$ \\
\hline $\begin{array}{l}\text { Robertson CS et } \\
\text { al, } 2014\end{array}$ & $\begin{array}{l}\text { Baik pemberian eritropoetin maupun mempertahankan konsentrasi hemoglobin lebih } \\
\text { dari } 10 \mathrm{~g} / \mathrm{dl} \text { tidak menghasilkan perbaikan hasil neurologis pada } 6 \text { bulan. Ambang ba- } \\
\text { tas transfusi } 10 \mathrm{~g} / \mathrm{dl} \text { dikaitkan dengan insiden kejadian tromboemboli yang lebih tinggi }\end{array}$ \\
\hline
\end{tabular}


restriktif. Hanya saja pada pasien dengan strategi transfusi restriktif didapatkan insiden pneumonia, ISK, DVT, bakterimia, dan syok sepsis yang lebih rendah. ${ }^{14}$ Hasil akhir fungsi neurologis yang baik juga didapatkan hasil yang sama pada pasien dengan threshold $\mathrm{Hb} 7 \mathrm{mg} / \mathrm{dL}$ maupun 10 $\mathrm{mg} / \mathrm{dL}$. Berbeda dengan temuan klinis, dalam beberapa penelitian ditemukan fakta terdapat peningkatan monitoring neurofisiologis dengan perbaikan otak yang nyata. Transfusi eritrosit meningkatkan oksigenasi jaringan otak pada pasien anemia dengan cedera kepala berat dengan batas bawah oksigen jaringan otak $\left(\mathrm{PtiO}_{2}\right)$ $<15$ mmHg. ${ }^{15}$ Berikut tabel yang memberikan perbandingan manfaat dan kerugian dilakukan transfusi pada praktik neuroanestesi serta target $\mathrm{Hb}$ yang direkomendasikan (Tabel 3). Tabel 4 menjelaskan beberapa penelitian selama dekade terakhir yang mempengaruhi praktik transfusi pada neuroanestesi.

Saat transfusi dikerjakan pada pembedahan saraf, perlu dipertimbangkan juga mengenai produk darah yang akan digunakan. Kehilangan volume darah yang cukup masif dan digantikan hanya dengan pemberian PRC akan menyebabkan jumlah faktor pembekuan turun hingga 30\% dari batas bawah. Nilai ini merupakan nilai minimal yang harus dipertahankan agar tubuh tetap bisa mempertahankan hemostasis nya dengan adekuat. Sehingga pada batas ini perlu dipertimbangkan transfusi FFP untuk menggantikan faktor pembekuan yang hilang. Dalam penelitian terbaru disebutkan, pada pasien trauma dapat diberikan transfusi agresif sedini mungkin menggunakan FFP dan PRC dengan rasio 1:1 untuk memperbaiki survival rate pada kasus perdarahan masif. ${ }^{16}$ Metode ini dikenal dengan istilah haemostatic damage control atau formula-driven resuscitation dan telah mendapat banyak perhatian dunia karena berkaitan dengan angka survival rate yang tinggi di fase awal ataupun lanjutan dan menurunkan angka kematian akibat perdarahan. Meskipun terdapat beberapa kendala antara lain diperlukan akses yang cepat terhadap kebutuhan donor FFP. ${ }^{17}$ Pada beberapa periode terakhir, terdapat persetujuan dan guideline yang menyatakan bahwa kadar $\mathrm{Hb}$ kurang dari $7 \mathrm{~g} / \mathrm{dL}$ pada pasien dengan sakit berat dan cedera otak traumatik memerlukan transfusi PRC. ${ }^{18}$ Meskipun masih belum ada batas pasti mengenai pemberian transfusi pada kadar $\mathrm{Hb}$ 7-10 g/dL. Dalam penelitian yang sebagian besar quality of evidence nya rendah, disebutkan bahwa tidak ada perbedaan pada fungsi neurologis pada pasien dengan pemberian transfusi restriktif maupun liberal dengan kadar $\mathrm{Hb} 7-10 \mathrm{~g} / \mathrm{dL}$. Pada guideline klinis terkini merekomendasikan kadar $\mathrm{Hb}$ di rentang 7-9 g/dL pada pasien trauma dan pasien dengan perawatan kritis. ${ }^{19}$ Guideline dari American Society of Anesthesiologists merekomendasikan penggunaan strategi transfusi restriktif, $\mathrm{Hb}$ kurang dari $8 \mathrm{~g} / \mathrm{dL}$ dan nilai hematokrit kurang dari 25\% untuk mengurangi transfusi PRC tanpa meningkatkan resiko hasil akhir yang buruk ataupun komplikasi pada fungsi neurologis dan kardiopulmonal. ${ }^{20}$ Rekomendasi serupa juga dikeluarkan oleh The British Committee for Standards in Haemoatology namun pada kasus iskemia serebri, target $\mathrm{Hb}$ dinaikkan hingga lebih dari $9 \mathrm{~g} / \mathrm{dL}$. Sedangkan menurut The American Association of Blood Banks (AABB) merekomendasikan pemberian transfusi dengan metode restriktif, dengan tetap memperhatikan konsentrasi $\mathrm{Hb}$ pada praktik klinisnya, kondisi klinis secara umum, dan terapi alternatif saat mempertimbangkan keputusan transfusi kepada setiap individu. ${ }^{18}$ Keluaran klinis pasien pasca operasi yang diawasi selama perawatan di ICU juga menunjukkan kondisi yang baik. Hb dan Hct yang diperiksa pasca operasi juga menunjukkan nilai yang baik. Sehingga pada kasus ini, tatalaksana pemberian transfusi pada kasus cedera otak traumatik dengan metode neuroanestesi yang disesuaikan dengan mayoritas pedoman yang dipakai saat ini memberikan hasil akhir yang baik pada pasien ini.

\section{Simpulan}

Epidural haemorrhage (EDH) merupakan salah satu bentuk cedera kepala dimana waktu adalah indikator yang harus diperhatikan dalam tatalaksananya. Evakuasi dan kontrol perdarahan harus dikerjakan dalam waktu singkat untuk menghindari cedera lebih lanjut. Praktik neuroanastesi, sebagai penunjang dalam tatalaksana cedera otak traumatik, sering 
diasosiasikan dengan kejadian kehilangan darah yang mengakibatkan kondisi anemia selama periode intra operatif dan pasca operatif. Meskipun anemia berkorelasi dengan hasil akhir yang buruk pada pasien cedera otak, transfusi sel darah merah untuk mengoreksi kondisi anemia juga berkorelasi dengan hasil akhir yang buruk pada pasien. Masih belum ada rekomendasi yang jelas mengenai pemberian transfusi, apakah restriksi atau masif, terkait dengan manfaat yang diberikan. Klinisi dari berbagai senter masih menggunakan strategi transfusi yang bervariasi. Guideline dari American Society of Anesthesiologists merekomendasikan penggunaan strategi transfusi restriktif, $\mathrm{Hb}$ kurang dari $8 \mathrm{~g} / \mathrm{dL}$ dan nilai hematokrit kurang dari $25 \%$ untuk mengurangi transfusi PRC tanpa meningkatkan risiko hasil akhir yang buruk ataupun komplikasi pada fungsi neurologis dan kardiopulmonal, dengan tetap memperhatikan konsentrasi $\mathrm{Hb}$ pada praktik klinisnya, kondisi klinis secara umum, dan terapi alternatif saat mempertimbangkan keputusan transfusi kepada setiap individu.

\section{Daftar Pustaka}

1. Mirza FAFJ. Traumatic brain injury. In: Ferri's Clinical Advisor. Elsevier; 2019:1339-1402.

2. Peters ME, Gardner RC. Traumatic brain injury in older adults: do we need a different approach? Concussion. 2018;3(3):CNC56.

3. Dash HH, Chavali S. Management of traumatic brain injury patients. Korean $\mathrm{J}$ Anesthesiol. 2018;7(1):12-21.

4. Ali Z, Hassan N, Syed S. Blood transfusion practices in neuroanaesthesia. Indian $\mathrm{J}$ Anaesth. 2014;58(5):622-28.

5. Alharbi H, Khawar N, Kulpa J, Bellin A, Proteasa S, Sundaram R. Neurological complications following blood transfusions in sickle cell anemia. Case Rep Hematol. 2017;2017:1-3.

6. Smith MJ, Le Roux PD, Elliott JP, Winn
HR. Blood transfusion and increased risk for vasospasm and poor outcome after subarachnoid hemorrhage. J Neurosurg. 2004;101(1):1-7.

7. McIntyre LA, Fergusson DA, Hutchison JS, Pagliarello G, Marshall JC, Yetisir E, et al. Effect of a liberal versus restrictive transfusion strategy on mortality in patients with moderate to severe head injury. Neurocrit Care. 2006;5(1):4-9.

8. East JM, Viau-Lapointe J, McCredie VA. Transfusion practices in traumatic brain injury. Curr Opin Anaesthesiol. 2018;31(2):219-26.

9. Subekti BE, Oetoro BJ, Rasman M, Bisri T. Manajemen anestesi untuk evakuasi epidural hemorrhage bersama dengan operasi fraktur cruris terbuka. J Neuroanestesi Indones. 2017;6(1):42-58.

10. Hawthorne G, Gruen RL, Kaye AH. Traumatic brain injury and long-term quality of life: Findings from an Australian study. J Neurotrauma. 2009;26(10):1623-33.

11. Woods M. Aspect of perioperative neuroscience practice. In: Smith B, Rawling P, Wicker P, Jones C editors., ed. Core Topics in Operating Departement Anaesthesia and Critical Care. Cambridge University Press; 2007:61-76.

12. Saleh SC. Neuroanestesia Klinik. (Surabaya, ed.). Zifatama Publisher; 2013.

13. Sakabe T, Matsumoto M.Effects of anesthetics agents and other drugs on cerebral blood flow, metabolism and intracranial pressure. In: Cottrell and Young's Neuroanesthesia. 5th ed. Mosby Elsevier; 2010:317-26.

14. George ME, Skarda DE, Watts CR, Pham HD, Beilman GJ. Aggressive red blood cell transfusion: No association with improved outcomesforvictimsofisolated traumaticbrain injury. Neurocrit Care. 2008;8(3):337-43. 
15. Leal-Noval SR, Rincón-Ferrari MD, MarinNiebla A, et al. Transfusion of erythrocyte concentrates produces a variable increment on cerebral oxygenation in patients with severe traumatic brain injury: A preliminary study. Intensive Care Med. 2006;32(11):1733-40.

16. Maegele M, Lefering R, Paffrath T, Tjardes T, Simanski C, Bouillon B. Red blood cell to plasma ratios transfused during massive transfusion are associated with mortality in severe multiply injury: A retrospective analysis from the Trauma Registry of the Deutsche Gesellschaft für Unfallchirurgie. Vox Sang. 2008;95(2):112-19.

17. Holcomb JB, Zarzabal LA, Michalek JE, et al. Increased platelet: $\mathrm{RBC}$ ratios are associated with improved survival after massive transfusion. J Trauma - Inj Infect Crit Care. 2011;71(2 SUPPL. 3).

18. Carson JL, Guyatt G, Heddle NM, Grossman BJ, Cohn CS, Fung MK, et al. Clinical practice guidelines from the AABB: Red blood cell transfusion thresholds and storage. JAMA - J Am Med Assoc. 2016;316(19):2025-35.

19. Rossaint R, Bouillon B, Cerny V, Coats TJ, Duranteau J, Mondejar EF, et al. The European guideline on management of major bleeding and coagulopathy following trauma: Fourth edition. Crit Care. 2016;20(1):1-55.

20. American Society of Anesthesiologists Task Force. Practice Guidelines for Perioperative Blood Transfusion. Pract Guidel Anesth. 2018;(2):243-75. 